\title{
Effect of colostrum on gravity separation of milk somatic cells in skim milk ${ }^{1}$
}

\author{
S. R. Geer and D. M. Barbano ${ }^{2}$ \\ Northeast Dairy Food Research Center, Department of Food Science, Cornell University, Ithaca, NY 14853
}

\section{ABSTRACT}

Our objective was to determine if immunoglobulins play a role in the gravity separation (rising to the top) of somatic cells (SC) in skim milk. Other researchers have shown that gravity separation of milk fat globules is enhanced by IgM. Our recent research found that bacteria and SC gravity separate in both raw whole and skim milk and that heating milk to $>76.9^{\circ} \mathrm{C}$ for 25 s stopped gravity separation of milk fat, SC, and bacteria. Bovine colostrum is a good natural source of immunoglobulins. An experiment was designed where skim milk was heated at high temperatures $\left(76^{\circ} \mathrm{C}\right.$ for $7 \mathrm{~min}$ ) to stop the gravity separation of SC and then colostrum was added back to try to restore the gravity separation of SC in increments to achieve $0,0.4,0.8$, 2.0 , and $4.0 \mathrm{~g} / \mathrm{L}$ of added immunoglobulins. The milk was allowed to gravity separate for $22 \mathrm{~h}$ at $4^{\circ} \mathrm{C}$. The heat treatment of skim milk was sufficient to stop the gravity separation of SC. The treatment of $4.0 \mathrm{~g} / \mathrm{L}$ of added immunoglobulins was successful in restoring the gravity separation of SC as compared with raw skim milk. Preliminary spore data on the third replicate suggested that bacterial spores gravity separate the same way as the SC in heated skim milk and heated skim milk with $4.0 \mathrm{~g} / \mathrm{L}$ of added immunoglobulins. Strong evidence exists that immunoglobulins are at least one of the factors necessary for the gravity separation of $\mathrm{SC}$ and bacterial spores. It is uncertain at this time whether SC are a necessary component for gravity separation of fat, bacteria, and spores to occur. Further research is needed to determine separately the role of immunoglobulins and SC in gravity separation of bacteria and spores. Understanding the mechanism of gravity separation may allow the development of a continuous flow technology to remove SC, bacteria, and spores from milk.

Key words: gravity separation, somatic cell, colostrum, immunoglobulin

\footnotetext{
Received August 11, 2013.

Accepted October 26, 2013.

${ }^{1}$ Use of names, names of ingredients, and identification of specific models of equipment is for scientific clarity and does not constitute any endorsement of product by the authors or Cornell University.

${ }^{2}$ Corresponding author: dmb37@cornell.edu
}

\section{INTRODUCTION}

A well-known phenomenon in bovine milk is the gravity separation, or rising to the top, of fat globules when milk is allowed to stand unagitated. It was determined that the fat globules rose quicker than predicted by Stokes' Law (Troy and Sharp, 1928). If the fat globules clustered together, the faster rising could be explained (Troy and Sharp, 1928). Fat globules in milk aggregate together in a similar fashion to aggregation of components in blood (Babcock 1889).

Bacteria rise to the top during gravity separation along with the fat. Several researchers looked at the composition of the bacteria species before and after gravity separation and found that some species of bacteria rose to the top more than others (Dellaglio et al., 1969; Abo-Elnaga et al., 1981; Franciosi et al., 2011). It has been estimated that between 67 to $99 \%$ of the initial bacteria rises to the cream layer after gravity separation (Abo-Elnaga et al., 1981).

Competition also exists between bacteria and fat, as milk that is higher in bacteria counts will have a higher percentage of total bacteria at the top but a lower percentage of total fat at the top compared with milk with a lower starting bacteria count (Caplan et al., 2013). Stadhouders and Hup (1970) showed that bacteria agglutinate in milk and become attached to the fat globules, suggesting a similar agglutinating process for fat and bacteria. Evidence also exists that spores rise to the top during gravity separation (Rossi, 1964; Dellaglio et al., 1969)

Very little research has looked at the gravity separation of somatic cells (SC) in milk. Similar to the rising of bacteria and fat, SC would concentrate in the top portion of the milk after gravity separation (Caplan et al., 2013). Caplan et al. (2013) also found a similar trend among the gravity separation of fat, bacteria, and $\mathrm{SC}$; however, SC and bacteria were more concentrated after $22 \mathrm{~h}$ at $4^{\circ} \mathrm{C}$ than the fat. The role of $\mathrm{SC}$ in the gravity separation of fat and bacteria is uncertain, as its unknown at this time if it is a necessary component.

What still is not well understood is the actual mechanism behind the gravity separation. In a series of research experiments by Mertens (1933a,b), he came up with 2 main points regarding the gravity separation of 
fat. The first is that a factor that affects gravity separation exists in skim milk that can be heat denatured. The second factor is that something in colostrum enhances gravity separation of milk. Previous work showed that pasteurization at temperatures $>76.9^{\circ} \mathrm{C}$ for $25 \mathrm{~s}$ prevented gravity separation of fat, bacteria, and SC in whole milk (Caplan et al., 2013), which agrees with results from Mertens (1933a). Furthermore, the fact that fat, bacteria, and SC all stop their gravity separation with heat is further evidence of a common mechanism.

Immunoglobulins are good candidates for the heatlabile component of the gravity separation of fat based on the fact that they are found in blood serum, colostrum, and milk of bovines and they have the capability to form agglutinations (Hurley and Theil, 2011). Colostrum is a rich source of immunoglobulins, which could explain why Mertens (1933b) found that the addition of colostrum increased the rate of gravity separation. Euber and Brunner (1984) showed that IgM was a necessary component for the gravity separation of fat. The addition of $\mathrm{IgM}$ to whole milk heated at $75^{\circ} \mathrm{C}$ for 30 min restored the creaming of fat, whereas the addition of IgG did not (Euber and Brunner, 1984). They also found that when they removed IgA and IgG from raw milk, no effect occurred on the creaming, but removal of IgM did reduce creaming (Euber and Brunner, 1984).

Immunoglobulins are a type of B-cell receptor that binds to antigens. The basic structure of an immunoglobulin consists of a Y-like structure that has 2 identical heavy chains and 2 identical light chains (Parham, 2009). The immunoglobulin molecule is held together by 2 disulfide bonds in the hinge. A disulfide bond also links together the heavy and light chain (Parham, 2009). It is possible that disulfide bonds in the immunoglobulin molecule are destroyed by heat, leading to conformational changes within the immunoglobulin molecule, causing it to lose its activity. Bovine milk and colostrum immunoglobulin are composed primarily of $\operatorname{Ig} \mathrm{A}, \operatorname{Ig} \mathrm{G}_{1}, \operatorname{IgG}_{2}$, and $\operatorname{IgM}$.

Two identical antigen-binding sites are found on each Y structure of the immunoglobulin molecule (Parham, 2009). The antigen-binding sites recognize carbohydrates or proteins on the surface of a pathogen (Parham, 2009). Variability exists between different antigen-binding sites, which determines which type of antigens it can bind to (Parham, 2009). Immunoglobulin $\mathrm{M}$ is involved in the first immune response when an antigen is detected and, therefore, has lower specificity (Hurley and Theil, 2011). Immunoglobulin $G$ is involved in the secondary immune response and has more specificity toward particular antigens (Hurley and Theil, 2011). Immunoglobulin A is the primary antigen found in mucosal secretions (Hurley and Theil, 2011).
Research in our laboratory has shown that SC will gravity separate in skim milk, in the absence of fat globules. Evidence exists (Euber and Brunner, 1984) that milk fat globule membrane material may be important in the gravity separation process, but not the actual fat globules themselves. It has been observed that homogenization will stop the gravity separation of fat milk. Euber and Brunner (1984) added IgM and skim milk membrane separately to homogenized milk. The addition of IgM had no effect on the gravity separation of fat, but the addition of the skim milk membrane restored the gravity separation. Milk fat globule membrane material is found in both whole milk and skim milk, which could explain why SC gravity separate in both skim and whole milks.

Little research was found comparing the concentrations of immunoglobulins in whole versus skim milk, but it appears that, at least for IgG, no change in concentration occurred after the cream was removed (Li-Chan et al., 1995). Although no literature found compares $\operatorname{IgM}$ and IgA in whole versus skim milk, a higher association of $\operatorname{IgM}$ and $\operatorname{Ig} A$ with fat exists than for $\operatorname{IgG}_{1}$ and $\mathrm{IgG}_{2}$ (Frenyo et al., 1986). It is possible, therefore, that the levels of IgM and IgA would be lower in skim milk. However, Euber and Brunner (1984) found that only $7 \%$ of the total amount of IgM present in whole milk is needed for gravity separation of fat. It is likely then that even if the immunoglobulin levels are lower in skim compared with whole milk, it is not enough to prevent the gravity separation of SC in skim milk.

More research is needed to understand how SC gravity separate in skim milk and whether SC play an important part in the gravity separation process. Our objective was to determine if immunoglobulins play a role in the gravity separation of SC in skim milk. Bovine colostrum served as a source of immunoglobulins, due to its high concentration of immunoglobulins compared with milk.

\section{MATERIALS AND METHODS}

\section{Experimental Design and Statistical Analysis}

An experiment was designed to determine if addition of raw colostrum (a crude source of bovine immunoglobulins) could restore gravity separation of SC for pasteurized $\left(>74.5^{\circ} \mathrm{C}\right.$ for $\left.25 \mathrm{~s}\right)$ skim milk. The experiment comprised 6 treatments: raw skim, pasteurized skim, and pasteurized skim milk with 4 levels of added immunoglobulins from colostrum $(0.4,0.8,2.0$, and $4.0 \mathrm{~g} / \mathrm{L}$ of added immunoglobulins). Six fractions were collected by weight, starting from the bottom of each gravity separation column (0 to $90 \%, 90$ to $92 \%, 92$ to $94 \%, 94$ to $96 \%, 96$ to $98 \%$, and 98 to $100 \%$ ) after 22 
$\mathrm{h}$ at $4^{\circ} \mathrm{C}$. The SCC was measured in the 6 fractions for each of the columns. The experiment was replicated 3 times in different weeks using a different batch of milk and different colostrum.

The GLM procedure of SAS (9.3; SAS Institute Inc., Cary, NC) was used to determine if level of addition of colostrum influenced the starting SCC of the 6 milks in the gravity separation columns. The ANOVA model had terms for level of colostrum addition and replicate as category variables. A linear regression analysis was done to determine if a significant correlation existed between the amount of colostrum added (i.e., estimated about of immunoglobulins added) and the amount of $\mathrm{SC}$ in the top $2 \%$ layer.

\section{Collection and Analysis of Colostrum}

Colostrum was obtained from Holstein cows at the Cornell University Teaching and Research Center on the first day of calving. The colostrum was placed on ice in a cooler held at $4^{\circ} \mathrm{C}$ until ready to use. The protein and fat level of the colostrum was determined using a Fourier-transform mid-infrared transmittance milk analyzer [LactoScope FTIR Advanced (FTA); Delta Instruments BV, Drachten, the Netherlands]. The calibration of the infrared milk analyzer was done as described by Kaylegian et al. (2006a,b), using a set of modified milk calibration samples. It was assumed that all the true protein in the colostrum higher than a concentration of $3 \%$ protein, the typical true protein level of milk, was due to immunoglobulins. This estimate of total immunoglobulin content was used to estimate the grams of immunoglobulin per liter of each colostrum. Fresh colostrum was obtained for each replicate of the experiment.

\section{Milk Processing}

Raw whole bulk tank milk was collected from Holstein cows at the Cornell University Teaching and Research Center (Ithaca, NY). The milk was mixed and separated at $4^{\circ} \mathrm{C}$ using a cream separator (model 372 Airtight; DeLaval Separator Co., Poughkeepsie, NY). One portion of the raw milk was held at $4^{\circ} \mathrm{C}$ and another portion of the raw skim milk (about $20 \mathrm{~kg}$ ) was batch pasteurized at $76^{\circ} \mathrm{C}$ for 7 min using a 38-L stainless steel jacketed steam kettle. Previous research (Caplan et al., 2013) has demonstrated that this heat treatment will prevent gravity separation. After $7 \mathrm{~min}$, about 17 L of pasteurized skim was collected and rapidly cooled in ice water and placed in a cooler at $4^{\circ} \mathrm{C}$.

Six 1-L glass gravity separation columns with a Teflon stopcock at the bottom (catalog no. 03-789-5c; Fisher Scientific, Pittsburg, PA) had been rinsed 3 times with a $200 \mathrm{mg} / \mathrm{kg}$ chlorine sanitizer solution and 3 times with a $70 \%$ ethanol solution the day before the experiment. Each column outlet was sanitized and had a sanitized Pasteur pipette bulb (catalog no. 03448-22; Fisher Scientific) on the bottom outlet to close the open glass tube with the stopcock closed and the top of the column capped with a rubber stopper. The empty columns were placed in a $4^{\circ} \mathrm{C}$ cooler. After pasteurization and cooling of the skim milk, 1 glass column was filled with raw skim milk and the other 5 were filled with pasteurized skim milk containing increasing amounts of added colostrum. The approximate weight of colostrum added was designed to provide about 0 , $0.4,0.8,2.0$, or $4.0 \mathrm{~g} / \mathrm{L}$ of added immunoglobulin to approximately $1,000 \mathrm{~mL}$ of milk in the gravity separation column. The milk and colostrum were added to the columns by weight. To ensure thorough mixing of the milk and colostrum before addition to the glass column, approximately $1,050 \mathrm{~g}$ of milk was added to a sanitized plastic 5.7-L container and the appropriate weight of colostrum was added. The milk plus colostrum was mixed thoroughly, about $50 \mathrm{~g}$ was poured into a $60-\mathrm{mL}$ sterile plastic snap-top vial (catalog no. CPP03CL; Capital Vial Inc., Amsterdam, NY) for analysis, and the rest was poured into the glass column and the weight of milk in each column was recorded. The top of the columns were closed with a stopper and immediately placed into a $4^{\circ} \mathrm{C}$ cooler and the milk was allowed to gravity separate for $22.67 \mathrm{~h}( \pm 3.1 \mathrm{~min})$.

\section{Sampling and Analysis of Milk Fractions}

The fat and SCC concentrations were measured for the raw whole milk, raw cream, colostrum, and the milk plus colostrum for each of the 6 columns. Six fractions were collected from each of the columns. The milk was collected by weight, starting from the bottom of the column. The bottom $90 \%$ was collected by weight into a sanitized plastic 1.9-L container. The top $10 \%$ layer was collected in 5 equal portions by weight directly into 45-mL sterile plastic snap-top vials (catalog no. CPP02CL; Capital Vial Inc.). The fractions collected were placed immediately into a $4^{\circ} \mathrm{C}$ cooler. Each fraction was analyzed for SCC. Fractions outside of the range of the instrument calibration (i.e., >1,000,000 SCC/mL) were diluted (wt/wt) using raw cold separated skim milk. A dilution factor was used to calculate the SCC of the undiluted fraction. The cream and colostrum were also diluted with skim milk before SCC analysis to reduce their viscosity and obtain a concentration of SC within the instrument's calibration range.

The fat content was determined (AOAC International, 2000; method 972.16) using a Fourier-transform infrared dairy analyzer (LactoScope FTIR; Delta 
Instruments BV). The SCC was determined (AOAC International, 2000; method 978.26) using fluorescence flow cytometry (SomaScope; Delta Instruments BV). A modified method (no. 8.090; Frank and Yousef, 2004) was used for mesophilic spore count analysis. Due to the low volume of the top column fractions, $5 \mathrm{~mL}$ of the milk was heated to $80^{\circ} \mathrm{C}$ for 12 min instead of 200 $\mathrm{mL}$ as stated in the method. For mesophilic spore count analysis, appropriate dilutions of the samples were made before plating to ensure that plate counts were in the countable range (between 25 and 250 cells $/ \mathrm{mL}$ ).

\section{RESULTS AND DISCUSSION}

\section{Composition and SCC of Whole Milk and Colostrum}

The SCC for the whole milk used in each replicate is shown in Table 1. The mean whole milk SCC of 241,000 $\mathrm{SCC} / \mathrm{mL}$ used in this study represents a typical bulk raw milk from the Cornell University dairy herd. For bulk tank milk, the US Department of AgricultureAgricultural Marketing Service has a milk quality payment system based on SCC in selected federal orders (USDA-AMS, 2012). Farms producing milk with SCC $<350,000$ cells $/ \mathrm{mL}$ receive more for their milk, whereas those with $>350,000$ cells $/ \mathrm{mL}$ receive a lower price for their milk. The mean SCC in colostrum (Table 1) was much higher than raw whole milk $(3,799,000$ vs. $241,000 / \mathrm{mL}$ ). The range of SC in colostrum was consistent with the findings of other researchers. In a sample of 69 Holstein cows, Ferdowsi Nia et al. (2010) found a range of 641,000 to $9,620,000$ cells $/ \mathrm{mL}$ for colostral SC.

The percentage true protein, percentage fat, and age of the colostrum for each replicate are shown in Table 2 . The amount of true protein and fat varied among the 3 colostrums.

Moody et al. (1951) also found that the protein and fat varied considerably in colostrum, with fat ranging from approximately $1 \%$ to almost $14 \%$ and protein ranging from about $9 \%$ to over $20 \%$. Our ranges in Table 2 are consistent with their findings.

Table 1. Somatic cell count per milliliter (mean \pm 1 SD) for the raw whole milk and colostrum for each replicate

\begin{tabular}{lcc}
\hline $\begin{array}{l}\text { Starting } \\
\text { material }\end{array}$ & Replicate & $\mathrm{SCC} / \mathrm{mL}$ \\
\hline Raw whole milk & 1 & 215,000 \\
& 2 & 256,000 \\
& 3 & 252,000 \\
Colostrum & Mean & $241,000 \pm 23,000$ \\
& 1 & $3,905,000$ \\
& 2 & $5,428,000$ \\
& 3 & $2,053,000$ \\
& Mean & $3,795,000 \pm 1,690,000$ \\
\hline
\end{tabular}

We accounted for differences in the protein content among colostrums to estimate the total amount of immunoglobulins that was added to each gravity separation column for each replicate. We assumed that all protein over 3\% was immunoglobulins. Differences could have existed in the proportions of different types of immunoglobulins from one experimental replicate to another among the 3 different colostrums. The relative proportion of the different types of individual immunoglobulins in the colostrums used in this study was not measured.

The fat content also varied among the 3 colostrums (Table 2). The fat content of colostrum was much higher for the first replicate than the other 2 replicates. We did not account for variation in fat when adding colostrum to the skim. The age of the colostrum at the time of the experiment differed slightly among replicates, varying between 2.9 and $5 \mathrm{~d}$, depending on the day the cow had its calf. The colostrum was collected on the first day of calving for all replicates. The colostrum for each replicate was held on ice in a $4^{\circ} \mathrm{C}$ cooler before the each replicate. We observed variation in composition of colostrum from cow to cow and we did not know if cow-to-cow variation and age of colostrum at time of use in the experiment would influence the effectiveness of colostrum addition. Therefore, we used 3 different colostrums in the experiment and report the age of the colostrum at use.

\section{Starting SCC of Skim Milks in the Gravity Separation Columns}

The initial SCC per milliliter and the amount of colostrum added (g) to achieve the target immunoglobulin addition for each treatment and replicate are shown in Table 3. An effect $(P<0.05)$ was observed of added colostrum and replicate on SCC of the milk plus colostrum mixture, with SCC increasing linearly $(P<0.05)$ as the amount of added colostrum increased $\left(\mathrm{R}^{2}=0.90\right)$. This was expected because adding more colostrum would also add more SC. Variability in starting milk SCC per milliliter in the columns (Table 3) among replicates was expected because of differences in SCC among the 3 different colostrums (Table 2). The amount of colostrum added to each treatment (Table 3 )

Table 2. The percentage of true protein and fat in the colostrum and the age of the colostrum at the time of the experiment

\begin{tabular}{lccc}
\hline Replicate & $\begin{array}{c}\text { True } \\
\text { protein } \\
(\%)\end{array}$ & $\begin{array}{c}\text { Fat } \\
(\%)\end{array}$ & $\begin{array}{c}\text { Age of } \\
\text { colostrum } \\
(\mathrm{d})\end{array}$ \\
\hline 1 & 22.1 & 9.64 & 4.7 \\
2 & 16.1 & 3.84 & 2.9 \\
3 & 15.4 & 3.60 & 5.0 \\
\hline
\end{tabular}


Table 3. The initial SCC per milliliter, the amount of colostrum added, and the percentage of somatic cells (SC) in the top $2 \%$ layer after gravity separation for $22 \mathrm{~h}$ at $4^{\circ} \mathrm{C}$ for the raw skim milk and the 5 pasteurized skim milk treatments with added colostrum

\begin{tabular}{|c|c|c|c|c|c|c|}
\hline Treatment & $\begin{array}{l}\text { Colostrum added } \\
\text { (g/kg of milk) }\end{array}$ & $\begin{array}{c}\text { Estimated } \\
\text { immunoglobulin } \\
\text { added }(g / L)\end{array}$ & $\mathrm{SCC} / \mathrm{mL}$ & SE & $\begin{array}{l}\text { SC in top } \\
2 \% \text { layer } \\
(\%)\end{array}$ & SE \\
\hline Raw skim milk & - & - & $94,000^{\mathrm{c}}$ & 13,632 & $81.5^{\mathrm{a}}$ & 5.5 \\
\hline Pasteurized skim milk & $0^{\mathrm{e}}$ & 0 & $94,000^{\mathrm{c}}$ & 13,632 & $2.2^{\mathrm{c}}$ & 5.5 \\
\hline Pasteurized skim milk & $2.77^{\mathrm{d}}$ & 0.4 & $110,000^{\mathrm{bc}}$ & 13,632 & $2.4^{\mathrm{c}}$ & 5.5 \\
\hline Pasteurized skim milk & $5.64^{\mathrm{c}}$ & 0.8 & $117,000^{\mathrm{bc}}$ & 13,632 & $2.2^{\mathrm{c}}$ & 5.5 \\
\hline Pasteurized skim milk & $14.20^{\mathrm{b}}$ & 2.0 & $149,000^{\mathrm{b}}$ & 13,632 & $36.3^{\mathrm{b}}$ & 5.5 \\
\hline Pasteurized skim milk & $31.25^{\mathrm{a}}$ & 4.0 & $215,000^{\mathrm{a}}$ & 17,243 & $77.2^{\mathrm{a}}$ & 7.0 \\
\hline $\mathrm{R}^{2}$ & 0.99 & & 0.90 & & 0.96 & \\
\hline
\end{tabular}

${ }^{\mathrm{a}-\mathrm{e}}$ Means within a column with different superscript letters differ $(P<0.05)$.

varied from one replicate to another due to differences in the amount of protein from one colostrum to another (Table 2).

\section{Effect of Pasteurization of Skim Milk on Gravity Separation of SC}

Immunoglobulins in colostrum are likely to be at least partially responsible for the restoration of gravity separation in skim milk that was pasteurized at $75^{\circ} \mathrm{C}$ for 7 min. The 3 main immunoglobulins in colostrum are IgG, IgM, and IgA. Immunoglobulin $\mathrm{G}$ can be subdivided into $\operatorname{IgG}_{1}$ and $\operatorname{IgG}_{2}$ (Hurley and Theil, 2011). All immunoglobulins share a common basic structure. Immunoglobulins are composed of 2 identical heavy chains and 2 identical light chains. Each heavy and light chain contains a variable and constant region (Hurley and Theil, 2011). Disulfide bonds link the heavy chains and light chains together, giving the molecule a Y-shaped structure (Hurley and Theil, 2011).

Differences exist in the overall structure of the $3 \mathrm{im}-$ munoglobulin classes in colostrum. Immunoglobulin G exists as a monomer, IgM exists as a pentamer, and $\operatorname{Ig} \mathrm{A}$ exists as a monomer and a dimer (Hurley and Theil, 2011). A joining chain links the monomeric immunoglobulin molecule together using a covalent bond to form the polymeric immunoglobulin (Hurley and Theil, 2011). Disulfide bridges are susceptible to degradation when exposed to high enough temperatures (Hurley and Theil, 2011). A degradation of the disulfide bridges would cause a loss of function of the immunoglobulin. Research by Caplan et al. (2013) showed that heating whole milk to above $76.9^{\circ} \mathrm{C}$ for $25 \mathrm{~s}$ caused a loss of gravity separation of fat and SC, possibly due to the breakage of the disulfide bonds in the immunoglobulins.

Mainer et al. (1997) examined the denaturation of $\operatorname{Ig} \mathrm{A}, \operatorname{IgG}$, and $\operatorname{IgM}$ in the temperature range of 62 to $81^{\circ} \mathrm{C}$. The order of denaturation was $\operatorname{IgM}, \operatorname{IgA}$, and $\operatorname{IgG}$, with IgG being the most heat stable out of the 3 (Mainer et al., 1997). For the 3 immunoglobulins, the longer the holding time at each temperature, the greater the degree of denaturation (Mainer et al., 1997). Based on their results, the time/temperature combination of $75^{\circ} \mathrm{C}$ for $7 \mathrm{~min}$ used in our experiment would result in significant degradation for the 3 immunoglobulins.

Figure 1 shows that the SC rose to the top of the column for the raw skim milk but did not for the pasteurized skim milk with no added colostrum; $81.5 \%$ and $2.2 \%$ of the SC were found in the top $2 \%$ layer for the raw skim and pasteurized skim milk, respectively (Table 3). These results show that the heat treatment used stopped the gravity separation of SC in skim milk, similar to the work performed by Caplan et al. (2013) on whole milk. This gives strong evidence that because immunoglobulins are destroyed by heat and heat can stop gravity separation, then immunoglobulins play at least some role in the gravity separation of SC in skim milk.

\section{Effect of Colostrum Addition to Pasteurized Skim Milk on Gravity Separation of SC}

A graph of the cumulative SC contained in the column after gravity separation as a function of the cumulative mass of milk removed from the bottom of the gravity separation columns for the 5 treatments $(0$, $0.4,0.8,2.0$, and $4.0 \mathrm{~g}$ of added immunoglobulins $/ \mathrm{L}$ ) is shown as Figure 1. If no gravity separation of $\mathrm{SC}$ occurred, then about $90 \%$ of the cumulative SC would be in the lower $90 \%$ of the gravity separation column and this was what was observed for pasteurized skim milk and pasteurized skim milk with 0.4 and $0.8 \mathrm{~g}$ of added immunoglobulins/L (Figure 1). In contrast, the lower $90 \%$ of the raw skim milk only contained about $10 \%$ of the SC originally present in the milk (Figure 1), indicating that substantial gravity separation (i.e., rising of SC to the top) occurred in raw skim milk. To demonstrate the degree of gravity separation of SC, the percentage of the starting SC in the milk that was in the top $2 \%$ of the weight of the milk in column is shown in Table 3. Raw skim milk had an average of 


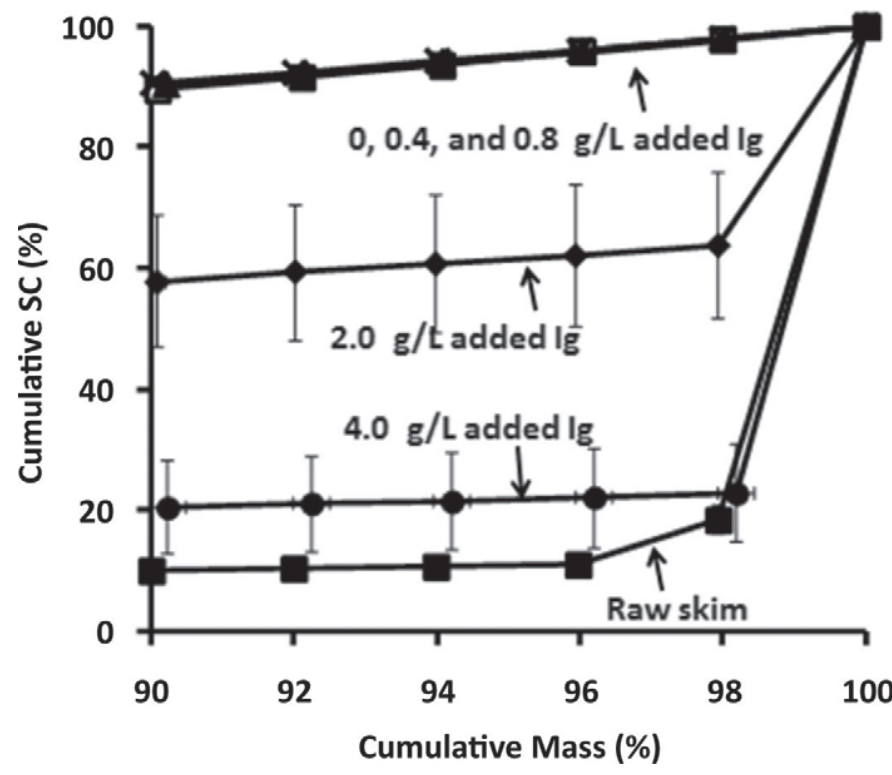

Figure 1. A comparison of the mean $(\mathrm{n}=3)$ of the cumulative somatic cell (SC) percentage accounted for as a function of cumulative mass percentage of milk for the 6 treatments: raw ( $)$ and pasteurized skim milk with $0(\square), 0.4(\mathbf{\Delta}), 0.8(\times), 2.0(\bullet)$, and $4.0(\bullet) \mathrm{g}$ of added immunoglobulins/L, for gravity separation at $4^{\circ} \mathrm{C}$ for $22 \mathrm{~h}$. Error bars represent $1 \mathrm{SE}$ from the mean. Note that for the treatment of $4.0 \mathrm{~g}$ of added immunoglobulin/L, $\mathrm{n}=2$.

$81.5 \%$ of total SC in the top $2 \%$ layer after $22 \mathrm{~h}$ of gravity separation at $4^{\circ} \mathrm{C}$, whereas no gravity separation of the $\mathrm{SC}$ was detected in the same milk that was pasteurized (Figure 1) at $75^{\circ} \mathrm{C}$ for $7 \mathrm{~min}$ and this was consistent with the results for whole milk presented previously by Caplan et al. (2013). No gravity separation of SC for pasteurized skim with 0.4 and $0.8 \mathrm{~g}$ of added immunoglobulins/L was detected $(P>0.05)$.

The error bars in Figure 1 show the variability within treatments between replicates. The treatments with 2.0 and $4.0 \mathrm{~g}$ of added immunoglobulins/L had the highest standard errors. Presumably, this was due to differences in the immunoglobulin content in the protein in colostrum among the 3 different cows used in our study. The amount of immunoglobulins added and the differences in the proportion of each type of immunoglobulin (e.g., IgG, IgM, and IgA) could affect how well the milk gravity separated.

Gravity separation of SC for pasteurized skim with 2.0 and $4.0 \mathrm{~g}$ of added immunoglobulins/L was compared with the raw skim milk treatment. Thirty-six and $77.2 \%$ of the SC was recovered (for the 2.0 and $4.0 \mathrm{~g}$ of added immunoglobulins/L, respectively) in the top $2 \%$ layer compared with $81.5 \%$ in the raw skim milk (Table 3). This value for percentage of SC in the top $2 \%$ layer for the $2.0 \mathrm{~g}$ of added immunoglobulins/L was lower $(P<0.05)$ than the raw milk and $4.0 \mathrm{~g}$ of added immunoglobulins/L, indicating partial restoration of gravity separation. No difference in the percentage of $\mathrm{SC}$ in the top $2 \%$ between the raw milk and the pasteurized milk with $4.0 \mathrm{~g}$ of added immunoglobulins/L was detected $(P>0.05)$, indicating that $4 \mathrm{~g}$ of added immunoglobulins/L restored the gravity separation of SC in pasteurized skim milk (Table 3). This is similar to the results of Jenness and Parkash (1971), who observed that immunoglobulins isolated from colostrum and added to pasteurized $\left(85^{\circ} \mathrm{C}\right.$ for $\left.30 \mathrm{~min}\right)$ whole milk restored the gravity separation of fat.

As the amount of immunoglobulins added to pasteurized skim milk increased, the percentage of total SCC that were in top $2 \%$ layer after $22 \mathrm{~h}$ at $4^{\circ} \mathrm{C}$ increased linearly, in a dose response relationship (Figure 2). As mentioned before, colostrum from a different cow was used for each replicate. Cows differ in the properties of their colostrum (Korhonen et al., 2000) and that difference could affect the relative proportion of immunoglobulins in the protein. The total immunoglobulin content of colostrum can vary considerably (from 30 to $200 \mathrm{mg} / \mathrm{mL}$ ) between cows due to variations between breeds and differences in age, health status, and lactation stage (Korhonen et al., 2000). Roughly 70 to $80 \%$ of the true protein content of colostrum is made up of immunoglobulins (Korhonen et al., 2000). Although all the colostrum used in this experiment was taken from the cows on the first day of calving, differences in the age and health status as well as time taken after calving might cause differences in the immunoglobulin composition among the 3 colostrums used for this experiment.

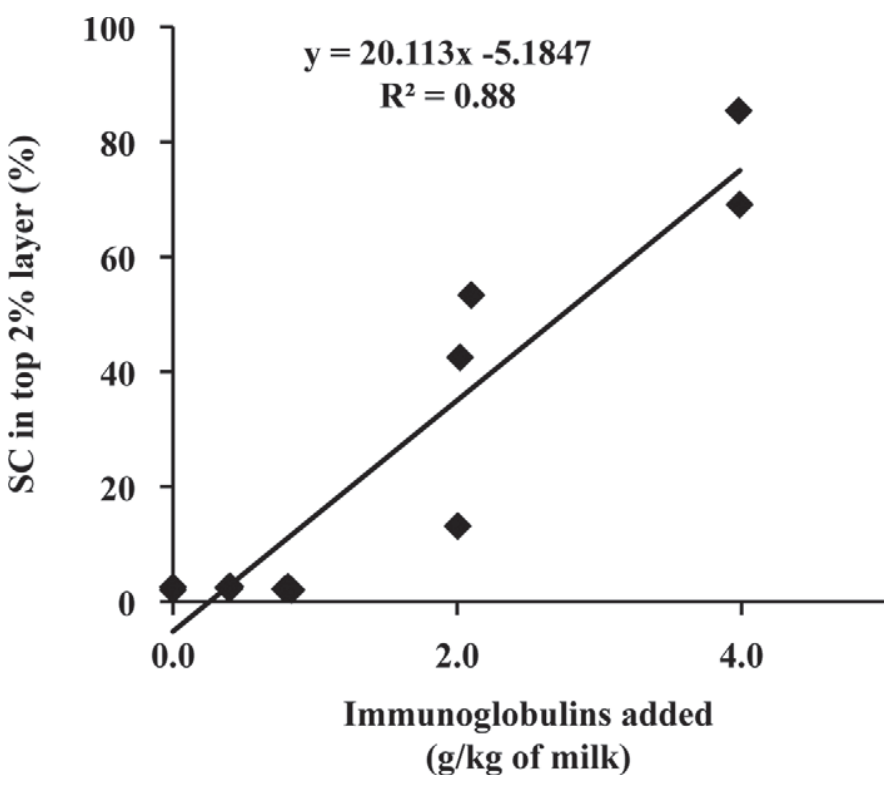

Figure 2. The percentage of the total somatic cells (SC) in the top $2 \%$ layer of the gravity separation columns for pasteurized skim milk after $22 \mathrm{~h}$ at $4^{\circ} \mathrm{C}$ as a function of the amount of immunoglobulin added (g) from the colostrum. 
This could cause variation in observed completeness in gravity separation among replicates for each treatment.

For the last replicate of the experiment, the bacteria spore count was measured for the 0 to $90 \%$ and 98 to $100 \%$ fractions for the column with raw skim milk and 3 of the columns with pasteurized skim milk $(0,2.0$, and $4.0 \mathrm{~g}$ of added immunoglobulins/L). The spores gravity separated in a fashion similar to the SC. For the raw skim milk, $80.4 \%$ of the spores were found in the top $2 \%$ layer. The percentage of spores in the top $2 \%$ layer was $1.7,3.8$, and $22.6 \%$ for the $0,2.0$, and $4.0 \mathrm{~g}$ of added immunoglobulins/L, respectively. Future work should examine if the gravity separation of vegetative bacterial cells and spores are similar to the gravity separation of SC in skim milk (Figure 1) and bacteria in whole milk (Caplan et al., 2013).

\section{CONCLUSIONS}

Heat treatment of skim milk $\left(76^{\circ} \mathrm{C}\right.$ for 7 min $)$ was sufficient to stop the gravity separation of SC. Colostrum was added back to heated skim in increasing increments to achieve $0,0.4,0.8,2.0$, and $4.0 \mathrm{~g}$ of added immunoglobulins/L. The treatment of $4.0 \mathrm{~g}$ of added immunoglobulins/L was successful in restoring the gravity separation of SC compared with raw skim milk. Preliminary spore data from the third replicate suggested that bacterial spores gravity separate the same way as the SC in heated skim milk and heated skim milk with $4.0 \mathrm{~g}$ of added immunoglobulins/L. Strong evidence exists that immunoglobulins are at least one of the factors necessary for the gravity separation of $\mathrm{SC}$ and bacterial spores. It is uncertain at this time whether SC are a necessary component for gravity separation of fat, bacteria, and spores to occur. Further research will need to examine separately the role of immunoglobulins and SC.

\section{ACKNOWLEDGMENTS}

The authors thank the New York State Milk Promotion Board (Albany, NY) for partial funding of this research. The authors thank the following staff members of Cornell University (Ithaca, NY): Tim Barnard, Steve Beckman, Michelle Bilotta, Gladys Birdsall, Sara Bova, and Chassidy Coon, for technical assistance and Karen Wojciechowski (Department of Food Science, Cornell University) for her input on immunoglobulins, complement factors, and experimental design.

\section{REFERENCES}

Abo-Elnaga, I. G., N. H. Metwally, and E. M. M. El-Mansy. 1981. The bacterial content of creamed milk. Archiv für Lebensmittelhygiene, Fleisch-, Fisch- und Milchhygiene 32:19-21.

AOAC International. 2000. Official Methods of Analysis. 17th ed. AOAC International, Arlington, VA.
Babcock, S. M. 1889. The constitution of milk, and some of the conditions which affect the separation of cream. University of Wisconsin Agricultural Experiment Station Bulletin 18:3-35.

Caplan, Z., C. Melilli, and D. M. Barbano. 2013. Gravity separation of fat, somatic cells, and bacteria in raw and pasteurized milks. J. Dairy Sci. 96:2011-2019.

Dellaglio, F., J. Stadhouders, and G. Hup. 1969. Distribution of bacteria between the bottom, middle, and cream layers of creamed raw milk. Neth. Milk Dairy J. 23:140-145.

Euber, J. R., and J. R. Brunner. 1984. Reexamination of fat globule clustering and creaming in cow milk. J. Dairy Sci. 67:2821-2832.

Ferdowsi Nia, E., A. Nikkhah, H. R. Rahmani, M. Alikhani, M. Mohammad Alipour, and G. R. Ghorbani. 2010. Increased colostral somatic cell counts reduce pre-weaning calf immunity, health and growth. J. Anim. Physiol. Anim. Nutr. (Berl.) 94:628-634.

Franciosi, E., G. De Sabbata, F. Gardini, A. Cavazza, and E. Poznanski. 2011. Changes in psychotropic microbial populations during creaming to produce Grana Trentino cheese. Food Microbiol. 28:43-51.

Frank, J. F., and A. E. Yousef. 2004. Test for group of microorganisms, Pages 227-248 in Standard Methods for the Examination of Dairy Products. 17th ed. H. M. Wehr and J. F. Frank, ed. Am. Public Health Assoc., Washington, DC.

Frenyo, V. L., J. E. Butler, and A. J. Guidry. 1986. The association of extrinsic bovine $\operatorname{IgG}_{1}, \operatorname{IgG}_{2}$, SIgA and IgM with the major fractions and cells of milk. Vet. Immunol. Immunopathol. 13:239-254.

Hurley, W. L., and P. K. Theil. 2011. Perspective on immunoglobulins in colostrum and milk. Nutrients 3:442-474.

Jenness, R., and S. Parkash. 1971. Lack of a fat globule clustering agent in goats' milk. J. Dairy Sci. 54:123-126.

Kaylegian, K. E., G. E. Houghton, J. M. Lynch, J. R. Fleming, and D. M. Barbano. 2006a. Calibration of infrared milk analyzers: Modified milk versus producer milk. J. Dairy Sci. 89:2817-2832.

Kaylegian, K. E., J. M. Lynch, G. E. Houghton, J. R. Fleming, and D. M. Barbano. 2006b. Modified versus producer milk calibration: mid-infrared analyzer performance validation. J. Dairy Sci. 89:2833-2845.

Korhonen, H., P. Marnila, and H. S. Gill. 2000. Milk immunoglobulins and complement factors. Br. J. Nutr. 84(Suppl. 1):S75-S80.

Li-Chan, E., A. Kummer, J. N. Losso, D. D. Kitts, and S. Nakai. 1995. Stability of bovine immunoglobulins to thermal treatment and processing. Food Res. Int. 28:9-16.

Mainer, G., L. Sánchez, J. M. Ena, and M. Calvo. 1997. Kinetic and thermodynamic parameters for heat denaturation of bovine milk IgG, IgA and IgM. J. Food Sci. 62:1034-1038.

Mertens, E. 1933a. Beiträge zum Aufrahmungsproblem. I. Mitteilung. Praktische Versuche zum Problem der Aufrahmung. Milchwirtschaftliche Forschungen 14:1-20.

Mertens, E. 1933b. Beiträge zum Aufrahmungsproblem. IV. Mitteilung. Anreicherung von capillaraktiven natürlichen Milchbestandteilen in Milch zur Verbesserung der Aufrahmung. Milchwirtschaftliche Forschungen 14:37-42

Moody, E. G., G. H. Wise, D. B. Parrish, and F. W. Atkeson. 1951. Properties of the colostrum of the dairy cow. VI. Creaming and rate of flow. J. Dairy Sci. 34:106-115.

Parham, P. 2009. The Immune System. 3rd ed. Garland Science, New York, NY.

Rossi, J. 1964. Sul processo di caseificazione del formaggio grana. Il Latte 38:301-305.

Stadhouders, J., and G. Hup. 1970. Complexity and specificity of euglobulin in relation to inhibition of bacteria and to cream rising. Neth. Milk Dairy J. 24:79-95.

Troy, H. C., and P. F. Sharp. 1928. Physical factors influencing the formation and fat content of gravity cream. J. Dairy Sci. 11:189229.

USDA-AMS (US Department of Agriculture-Agricultural Marketing Service). 2012. Price formulas. Accessed June 2, 2012. http://www. ams.usda.gov/AMSv1.0/ams.fetchTemplateData.do?template $=$ TemplateD\&navID=IndustryMarketingandPromotion\&leftNav= IndustryMarketingandPromotion\&page $=$ PriceFormulas2012\&acct $=$ dmktord. 